\title{
Geomorphological description of the biome Pampa (Brazil) with support of digital elevation model and geographic information system
}

\section{Descrição geomorfológica do bioma Pampa (Brasil) com apoio de modelo de elevação digital e sistema de informação geográfica}

\author{
Luís Eduardo de Souza Robaina* $\triangle(\mathbb{D}$, Romario Trentin $\bowtie$ (D), \\ Anderson Augusto Volpato Sccoti $ه$ (D)
}

Departamento de Geociências, Universidade Federal de Santa Maria, Santa Maria, Rio Grande do Sul, Brasil

Recebido (Received): 11/05/2020

E-mail: romario.trentin@gmail.com (RT); asccoti2@gmail.com (AAVS)

*E-mail para correspondência: lesrobaina@yahoo.com.br

Abstract: In Brazil, the Pampa Biome is restricted to the far south in the state of Rio Grande do Sul, where it occupies an area of $176,496 \mathrm{~km}^{2}$, which corresponds to $63 \%$ of the territory state and $2.07 \%$ of the Brazilian territory. The biome is characterized by the predominance of native fields with the presence of riparian forests, hillside forests, dwarf-palms fields, xerophyte bushes, wetlands, rocky outcrops, etc. Geomorphologically the landscape of the biome is very varied due to the lithological and structural conditions that interacted in the performance of surface processes. The landscapes consists of plains areas associated with Quaternary deposits; undulating reliefs associated with the sedimentary Basins, which consists of a volcano-sedimentary sequence by rocks formed in different depositional environments of the Paraná Basin and by rocks that represent a Plateau Volcanism and; a dissected plateau relief associated with the Precambrian crystalline basement. This paper describes quantitatively the relief through equations using Geographic Information Systems and the representation of the earth surface in the form of numerical digital models. Digital processing as well as the database were organized and managed by GIS, ArcGIS 10.3®, with spatial analysis and three-dimensional analysis tools. For each of the large geomorphological compartments that make up the Biome, a description of the landforms, and landforms elements were established and mapped. Relief shapes are described by the amplitude and slope of the terrain defined in flat areas, slightly undulations hills, undulating hills and large hills and buttes. For the determination of the relief elements the difference of topographic height, distance and the direction angle of the neighboring points in relation to the central cell (zenith and nadir angles) was used, through online application, available in the website $<<$ http://sil.uc.edu/geom/app >>. The relief elements determined are the flat, peak, ridge, shouder, spur, slope, hollow, footslope, valley, pit. The grouping of landforms and landform elements allowed the distinction of predominant morphological patterns for each geomorphological compartment in the Pampa Biome.

Keywords: Biome; Lanforms; Geomorphological; Landform elements.

Resumo: No Brasil, o bioma Pampa está restrito ao extremo sul do estado do Rio Grande do Sul, onde ocupa uma área de $176.496 \mathrm{~km}^{2}$, o que corresponde a $63 \%$ do território do estado e 2,07\% do território brasileiro. O bioma é caracterizado pela predominância de campos nativos com a presença de matas ciliares, florestas de encostas, campos de palmeiras-anãs, arbustos xerófitos, áreas úmidas, afloramentos rochosos, etc. Geomorfologicamente a paisagem do bioma é muito variada devido às características litológicas e estruturais. condições que interagiram no desempenho de processos de superfície. As paisagens consistem em áreas de planícies associadas a depósitos quaternários; relevos ondulantes associados às Bacias sedimentares, que consistem em uma sequência vulcão-sedimentar por rochas formadas em diferentes ambientes deposicionais da Bacia do Paraná e por rochas que representam um vulcanismo de platô e; um relevo de platô dissecado associado ao porções cristalino pré-cambriano. Este artigo descreve quantitativamente o relevo através de equações usando Sistemas de Informação Geográfica e a representação da superfície da Terra na forma de modelos digitais de elevação. O processamento digital e $o$ banco de dados foram organizados e gerenciados pelo GIS, ArcGIS 10.3®, com análise espacial e 
ferramentas de análise tridimensional. Para cada um dos grandes compartimentos geomorfológicos que compõem o Bioma, uma descrição das formas de relevo, elementos de relevo foram estabelecidos $e$ cartografados. As formas de relevo são descritas pela amplitude e inclinação do terreno definido em áreas planas, colinas suaves, colinas, morros e montes. Para a determinação dos elementos de relevo, foi utilizada a diferença de altura topográfica, distância e ângulo de direção dos pontos vizinhos em relação à célula central (ângulos zênite e nadir), por meio de aplicativo on-line, disponível no site <<http://sil.uc.edu/geom/app>>. Os elementos de relevo determinados são: área plana, pico, crista, ressalto, crista secundária, encosta, escavado, base da encosta, vale, fosso. $O$ agrupamento de formas $e$ elementos de relevo permitiu a distinção de padrões morfológicos predominantes para cada compartimento geomorfológico no Bioma Pampa.

Palavras-chave: Bioma; Formas de relevo; Geomorfologia; Elementos de relevo.

\section{Introduction}

The analysis of landforms is the basis of geomorphological studies, recording the results of the processes of surface dynamics and of the internal dynamics, defining the modeled surface. Landforms and geomorphological processes are of great importance, both because they constitute the physical substrate on which human activities are developed, and they often respond in a harmful way to interventions caused by such activities (ROSS, 1990).

The growing development of GIS with significant implementation of geoprocessing tools allow spatial and geomorphometric analysis with the representation of the Earth's surface as digital elevation models (DEM). These models enable the topographic analysis of areas of interest, as well as the automated calculation of a series of related geomorphological variables (VIDAL-TORRADO et al., 2005). According to Muñoz (2009), the parameters obtained from digital models are representative descriptors of quantitative relief measurements through equations applied to numerical models of altimetric representation. Trentin; Robaina (2016) classify the landform units supported by geomorphometric attributes

Studies that analyze patterns of similar landforms were carried out in the Plateau of Poços de Caldas / MG (MINATEL TINÓS et al., 2014), to determined Landforms in the Paraná State (SILVEIRA; SILVEIRA, 2015) and in the central region of Serra do Mar Paranaense (SILVEIRA; SILVEIRA, 2016); Santos et al. (2017) determined Landforms of the Jaguari River Basin, in the western region Rio Grande do Sul State; and Pineda et al. (2017) applies a geomorphological classification parameterized from the digital elevation model (DEM) and topographic attributes to mapping of the landforms and slopes in the basin of the river Neverí, Venezuela.

Schmidt and Hewitt (2004) developed procedures that allow different landform elements to be obtained, using the landscape position as a criterion, dividing it into flat areas and areas dissected. Iwahashi \& Pike (2007) present a method of automated topographic classification, without supervision, based on three morphometric variables: inclination, slope convexity and surface texture. Recently, Jasiewicz \& Stepinski (2013) established a classification of landform elements (geomorphons), using computer vision tools instead of differential geometry tools. The authors made an analogy between the textural classification of an image, based on the spatial arrangement of shades of gray, comparing with the specified distribution of the elevation values (DEM) of a given region. Trentin et al. (2016) analysis of landform elements through the topographic position index. Robaina et al. (2016) uses the method of geomorphons by determine the compartimentation of the Rio Grande do Sul state, through automated topographic analysis.

This work aims to develop an analysis of the landforms and landform elements in the various geomorphological compartments present in Pampa Biome, using GIS and geoprocessing. The Pampa Biome, in Brazil, is restricted to Rio Grande do Sul state, where it occupies an area of $176,496 \mathrm{~km}^{2}$ ((INSTITUTO BRASILEIRO DE GEOGRAFIA E ESTATÍSTICA (IBGE) 2004), which corresponds to $63 \%$ and $2.07 \%$ of the Brazilian territory (Figure 1). The biome is characterized by the predominance of native fields with the presence of riparian forests, hillside forests, fields of dwarf palms, xerophyte shrubs, humid areas, rocky outcrops, among others (IBGE, 2004). 


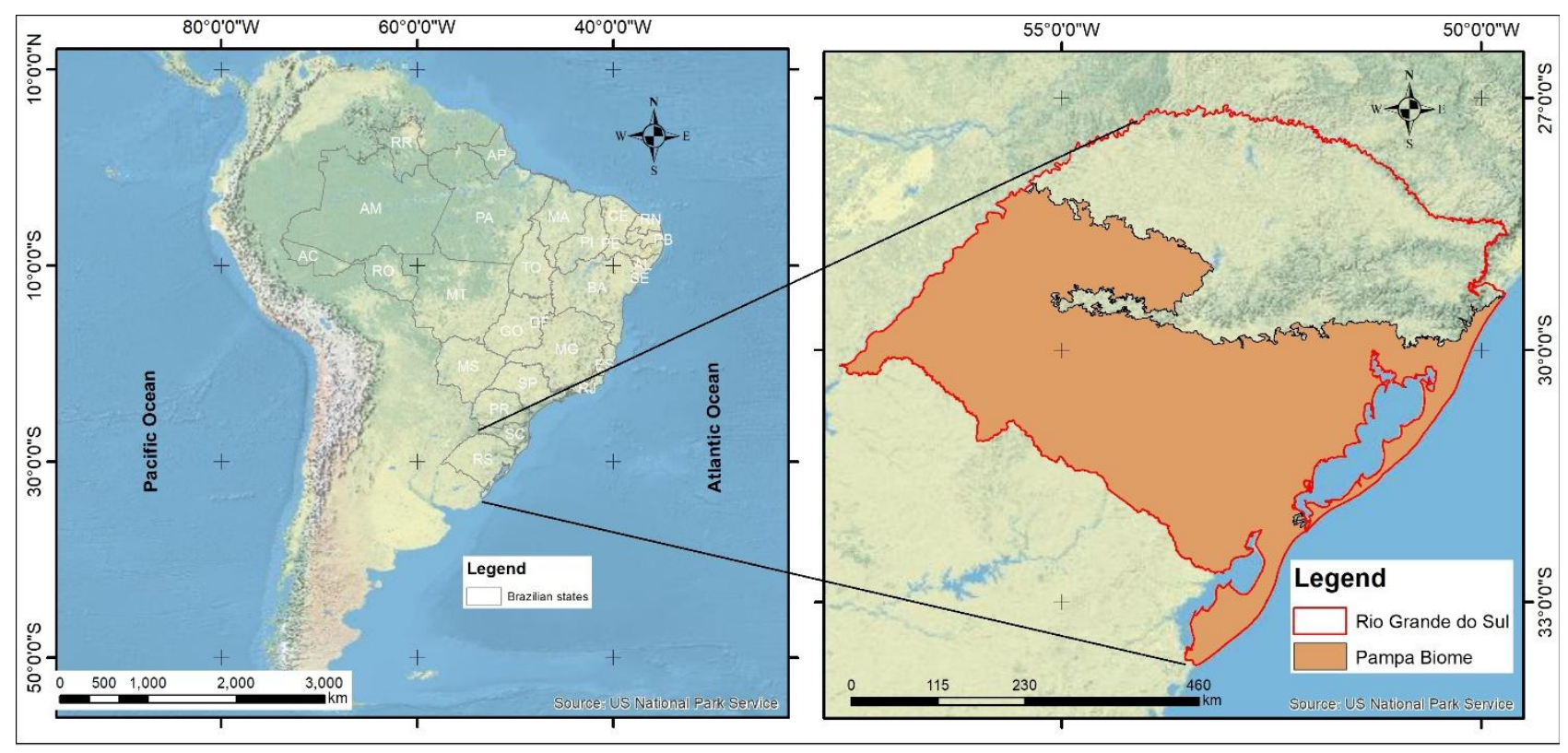

Figure 1: Location of the Pampa Biome in Brazil. Source: authors

\section{Methodology}

In the Brazilian territory six biomes are identified with different characteristics: Amazon, Caatinga, Cerrado, Atlantic Forest, Pampa and Pantanal. The spatial distribution of the Pampa Biome is based on the definition of data from the Ministério do Meio Ambiente (MMA, 2004) on the distribution of Brazilian Biomes.

The topographic base for the elaboration of the analyzes was the Digital Elevation Model, originated from the Shuttle Radar Topography Mission (SRTM) (KRETSCH, 2000), made available by the United States Geological Survey (U.S.GEOLOGICAL SURVEY, 2016), with spatial resolution of 3 arc-second (90 meters). The digital processes, as well as the database were organized and managed by the GIS, ArcGIS $10.3{ }^{\circledR}$, with the tools of spatial analysis and three-dimensional.

The geomorphological compartmentalization is based on the definitions of the RADAM BRASIL Project, referring 33 (IBGE, 1986). Morphostructural Domains (RADAM, 1986) that correspond: Domain of Sedimentary Deposits (Coastal Plains Internal and External); Domain of Sedimentary Basins and Coverings (Araucárias Plateau; Missões Plateau; Campanha Plateau; and Central Depression Gaúcha); Domain Basement in Complex Styles (Sul-Riograndense Rebaixado Plateau).

Landforms was analyzed by the landform elements. The landforms defined in the present work follow a proposal adapted from the Instituto de Pesquisas Tecnológicas (IPT, 1981), which uses the altimetric amplitude of 100 meters and the declivity interval of 5\% and 15\% (Table 1). This work was accented at intervals of $<2 \%$ and $2-5 \%$.

Table 1: Classification of landforms adapted from (IPT 1981)

\begin{tabular}{ccc}
\hline Altimetric amplitude & Declivity & Landforms \\
\hline \multirow{3}{*}{$<100$ meters } & $<2 \%$ & Flat Areas \\
& $2-5 \%$ & Slightly undulations hills \\
& 5 a $15 \%$ & Undulating hills \\
& $>15 \%$ & Large hills and buttes \\
\hline
\end{tabular}

The determine the landform elements, the proposed methodology of Jasiewicz \& Stepinski (2013) was used, which assesses the difference in topographic elevation, distance and direction angle of neighboring points in relation to the central cell through an online application, available at the site $<<$ http://sil.uc.edu/geom/app >>. The elevation angle is represented by the angle between the horizontal plane and the line connecting the central cell with the point on the profile. At a negative angle elevation, the point 
on the profile is lower than the central one. For each profile, the elevation angle "DSL" is calculated, with "D" and "L" showing the dependence of the direction (D) and the distance (L). Through these procedures, ten landform elements are defined by the app: flat, peak, ridge, shoulder, spur, slope, hollow, footslope, valley, pit.

\section{Results}

The natural landscapes of the Pampa Biome are characterized by the predominance of native fields, but there is also the presence of riparian forests, hillside forests, shrub formations, butiazais, wetlands, rock outcrops, etc. Lindman (1906), highlighting the presence of xerophilic characters in the fields, which mark the Pampa biome, indicates that they represent past drier climates than the current one. According to Marchiori (2004) who analyzed the phytogeography of Southern fields in Rio Grande do Sul, the differences in adaptation between woody and grassy species favor the interpretation that fields in the Pampa biome are relicts formations.

The Morphostructural Domain of Sedimentary Deposits comprises the regions of the Coastal Plains Internal and External; Domain of Sedimentary Basins and Coverings, the following regions occur: Araucárias Plateau; Missões Plateau; Campanha Plateau; and Central Depression Gaúcha, which can be divided into the Depression of the Rio Jacuí and the Depression of the Rio lbicuí-Rio Negro; Morphostructural Domain of Basement in Complex Styles is represented by the Geomorphological Region Sul-Riograndense Rebaixado Plateau (Figure 2 and Table 2).
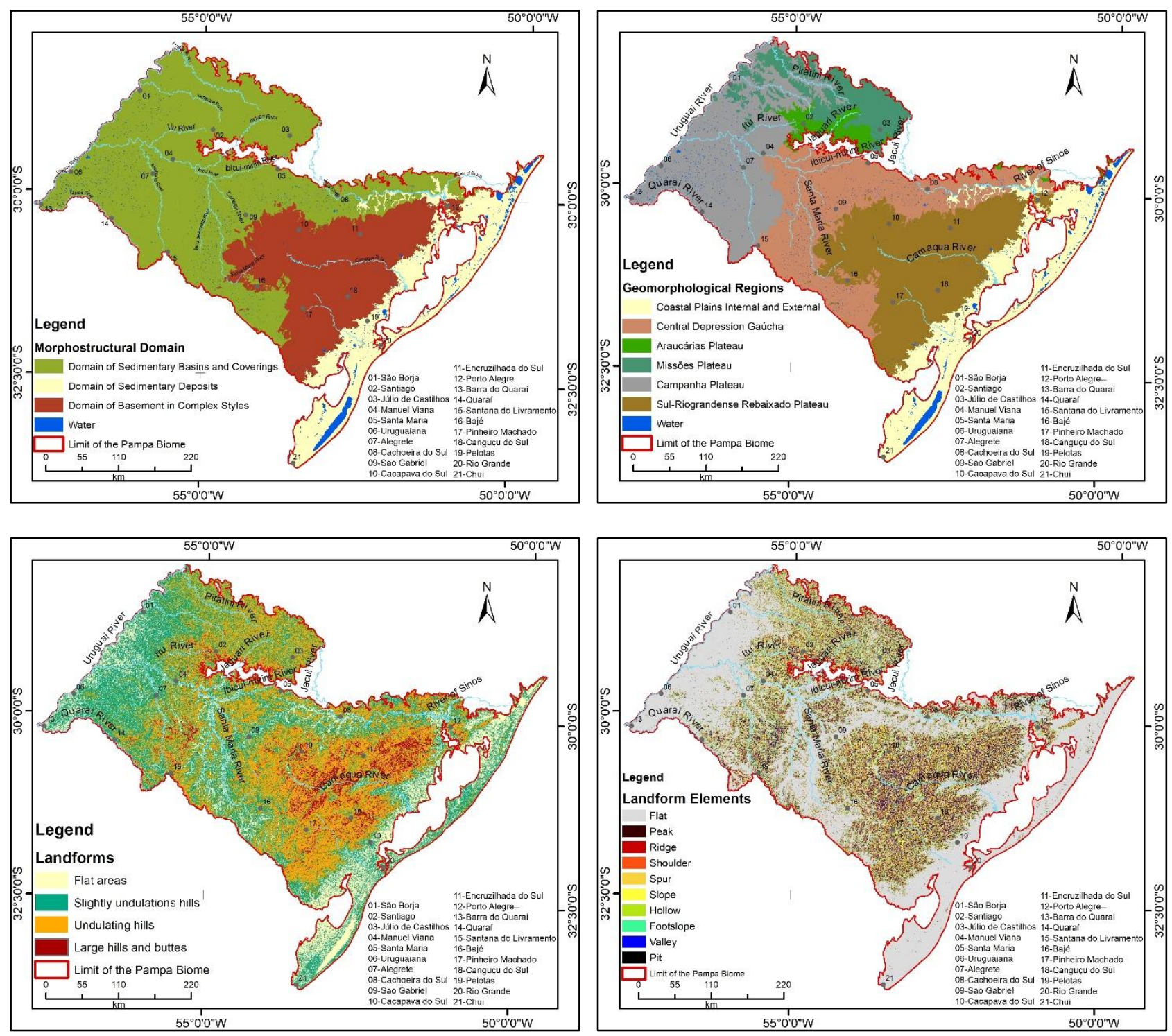

Figure 2: Compartmentation of the Pampa Biome - Geomorphological Domains - Geomorphological Regions - Landforms - Landform Elements. Source: authors 
Table 2: Shows the different geomorphological units indicating the area occupied and the percentage of representativeness in the Pampa Biome.

\begin{tabular}{lcc}
\hline Geomorphological Regions & Area $\mathbf{~ k m}^{\mathbf{2}}$ & Percentage \\
\hline Coastal Plains Internal and External & $60,109.17$ & 29.77 \\
Central Depression Gaúcha & $39,008.07$ & 19.32 \\
Araucárias Plateau & $4,677.02$ & 2.32 \\
Missões Plateau & $13,157.62$ & 6.52 \\
Campanha Plateau & $36,991.43$ & 18.32 \\
Sul-Riograndense Rebaixado Plateau & $43,930.04$ & 21.76 \\
Water & $4,012.24$ & 1.99 \\
\hline
\end{tabular}

\subsection{Morphostructural Domain of Sedimentary Deposits}

It constitutes a wide and extensive coastal area, generally sandy, where the formation of sandbanks occurred that isolated a series of lakes and formed the lagoon. In the region of the Coastal Plain Externa, marine coastal forms such as features related to marine terraces and wind action deposition, including dunes and sandy plains, develop. Secondarily there are lake plains on the banks of the larger lakes and the Patos lagoon, corresponding to 5\% of the area represented in Biome. The Coastal Plain Internal is characterized by deposits of continental origin, associated with lakes and the large Patos lagoon, making up $8.9 \%$ of the Biome's area.

In the Plains, dominate the modeled of accumulation developing a landforms of flat and slightly undulations hills areas. The Landforms identified as flat areas are characterized by slopes $<2 \%$, and define the areas of beaches, coastal plains and sand bars (Figure 3A) in the marine unit and the features of lake plains and marshy plains in the continental unit associated with the lagoon (Figure 3B).
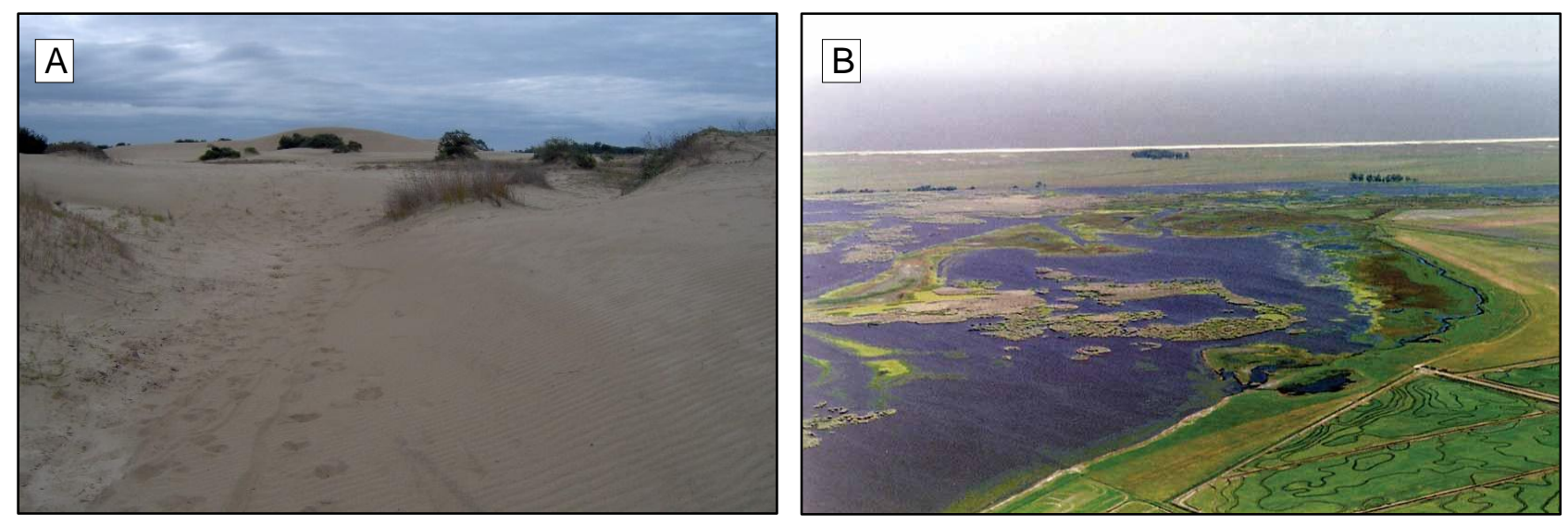

Figure 3: Photographs showing the landforms situations on the coastal plain. (A) Shoulder elements associated with dune areas; (B) Valley and hollow elements are associated with the river channels that flow into the lagoon. Source: Photography A: authors; Photography B: Villwock \&Tomazelli (2007)

The shapes of hills are characterized by elevations with amplitudes around $20 \mathrm{~m}$ and declivity between 2 and $5 \%$. These forms are relatively more common in the area where the marine features associated with the areas of dunes, paleodunes and, also, continuous elevations of sandy material deposited behind the beach.

In terms of landform elements, there is a great predominance of the flat element that characterizes the entire area of the Coastal Plain. Shoulder elements shoulder occur associated with hills in the dune areas, most common in the marine portion of the Plain.

In the continental portion, footslope and slope elements are relatively more prominent, which are associated with the presence of alluvial fan deposits, originating from the basement crystalline rocks. The valley and hollow elements are associated with the river channels that flow into the lagoon.

Figure 4 shows the statistical distributions of the forms and elements of relief in the Coastal Plains Internal and External and Figure 5 shows their respective spatial distributions. 

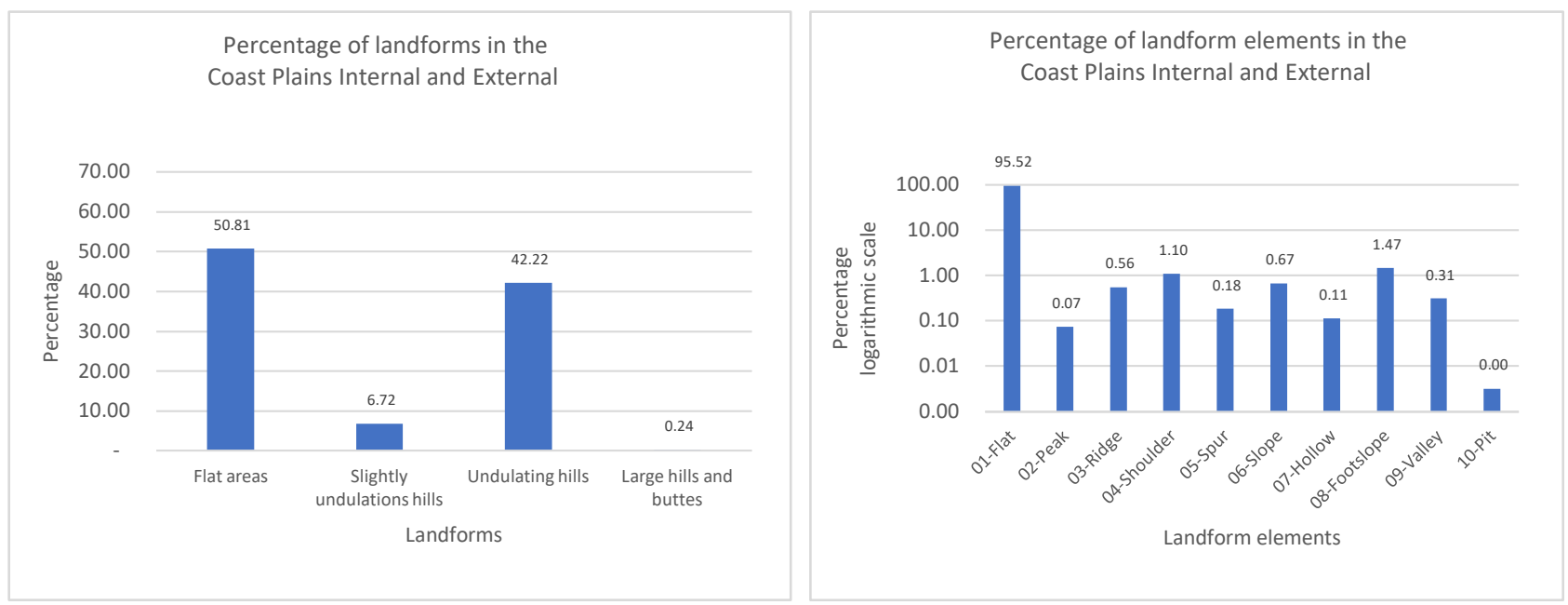

Figure 4: Percentage of landforms and elements on coastal plains. Source: Authors.
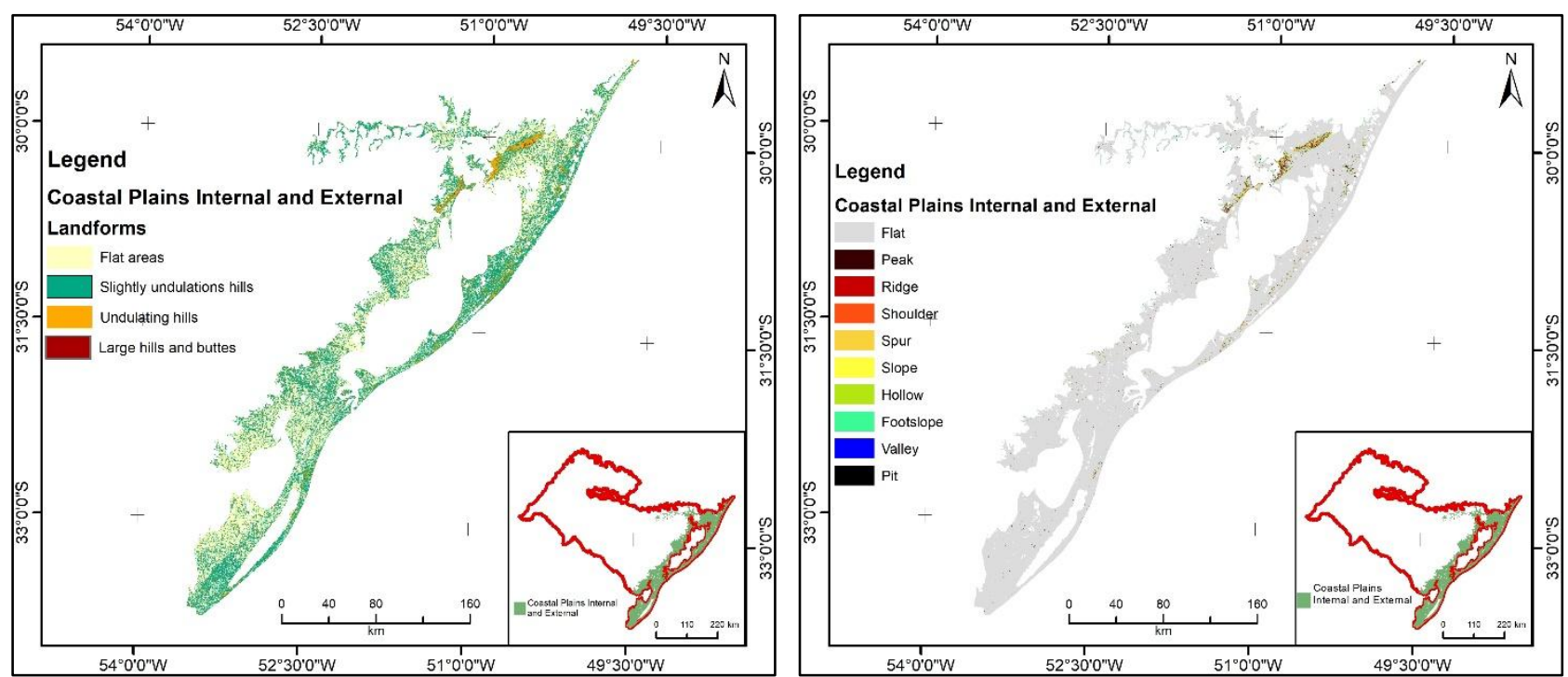

Figure 5: Spatial distribution of Landforms and landforms elements on coastal plains. Source: authors.

\subsection{Morphostructural Domain of Sedimentary Basins and Covers}

This domain include the rocks of the Paraná Basin, where the landforms were sculpted in lithologies of the sedimentation phase, between the Permian and the Eocretaceous, and of the effusive phase (MILANI $e t$ al. 2007).

In the Pampa Biome, in its northern portion there are the geomophological regions of the Araucárias Plateau and Missões Plateau. The Araucárias Plateau, corresponding to 2.8\% of the Biome's area, occurs in a strip between the Missões Plateau and the border of the Plateau, sculpted especially in acid effusive rocks of the Serra Geral Formation. The Missões Plateau is represented by predominantly acid and basic volcanic rocks, corresponding to almost $8 \%$ of the Biome's area.

In the Araucárias Plateau, a homogeneous dissection surface predominates, represented by landforms of undulating hills (inclination 5-15\%), with 59\%. In the portion towards the border of the Plateau the forms of large hills and buttes (Figure 6) are relatively more significant, while in the portions towards Missões Plateau the undulating hills are more important. 


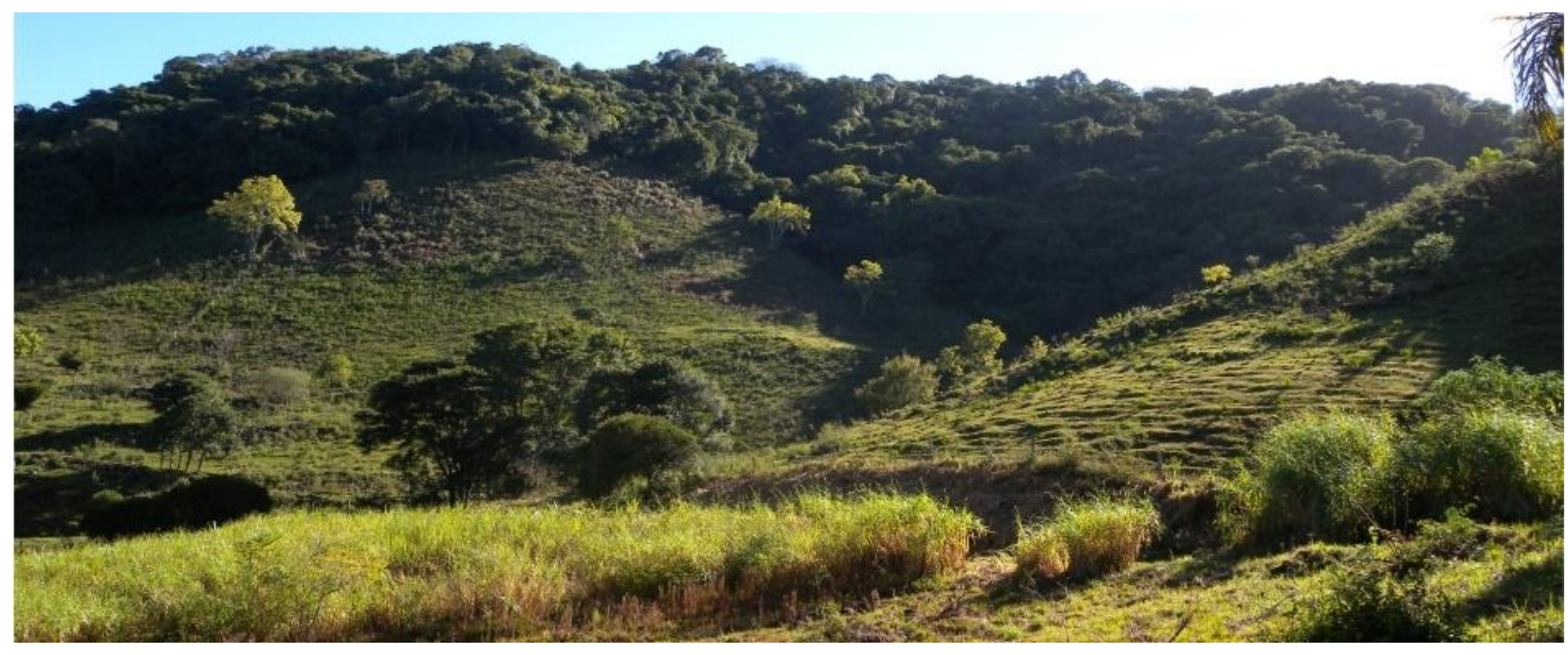

Figure 6: Photography showing the landforms situations on Araucárias Plateau in the portion towards the border of the Plateau. Source: author.

The predominant landform elements in undulating hills are slope element, while in the areas of smooths hills footslope elements are more important. The elements of ridges and valleys are important in the area of large hills and buttes.

At Missões Plateau the dissection processes that develop the undulating hills are the most important, making up 53\% of the lanforms and defining sector 01 (Figure 7A). In the west direction, the planing processes become relatively more important, and are represented by the relief of slightly undulations hills (Figure 7B) that occur in more than $42 \%$ of the landforms (sector 02).
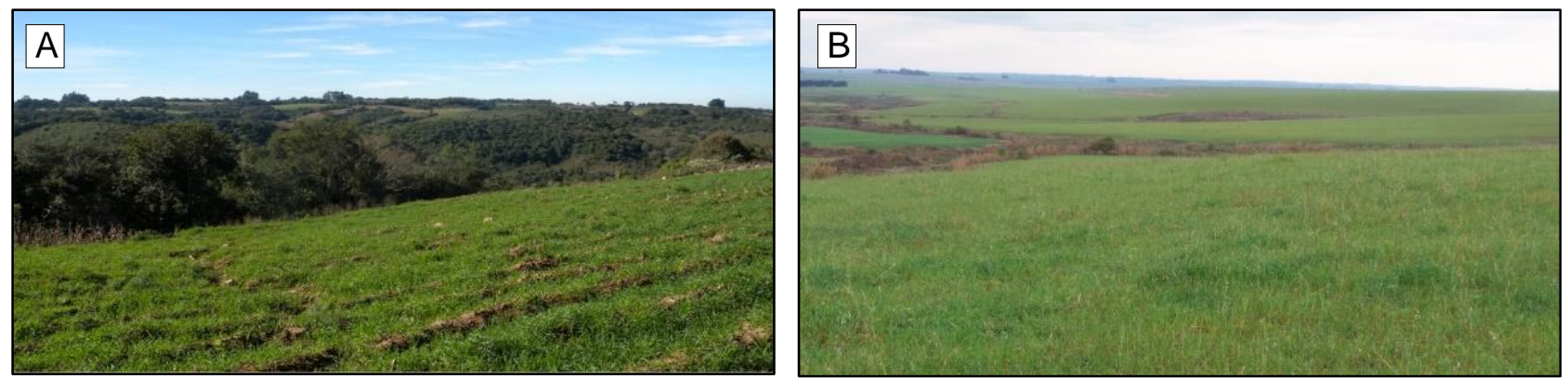

Figure 7: Photographs showing the landforms on Missões Plateau. Undulating hills with slope, valley and hollow element. Source: authors.

The planing process is represented by the predominance of flat element, with $30.4 \%$, and footslope with $17.7 \%$. Homogeneous dissection is characterized by a landforms where the slope element is more important. The steps formed by outcropping of rocks in more resistant portions are represented by the shoulder element which comprises $17.7 \%$ of the total elements.

The western portion of the Missões Plateau, defined as sector 02 towards the Campanha Plateau, forms of flat areas (inclination $<2 \%$ ) and slightly undulations hills (inclination $2-5 \%$ ) become dominant, marked by the significant presence of the flat type element. Figure 8 shows the percentages of the coverage area of the landforms and elements of landforms in the Araucárias Plateau and the Missões Plateau, in Figure 9 shows the respective spatial distributions. 


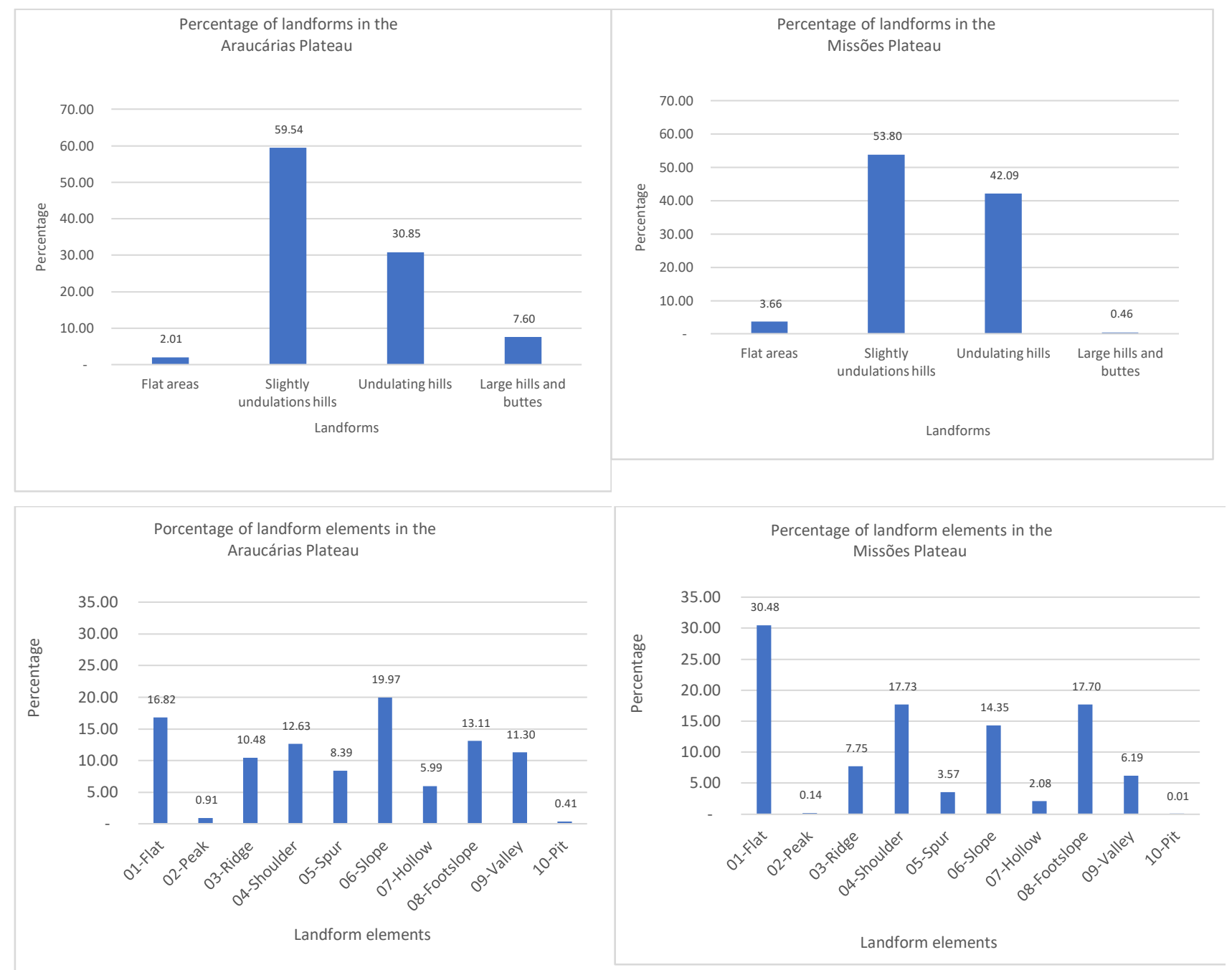

Figure 8: Percentage of landforms and elements in the Araucárias Plateau and Missões Plateau. Source: authors.

The Campanha Plateau is represented by an area of more than $22 \%$ of the Biome's area, it develops on volcanic rocks with shallow and poorly developed soils. This area of the Campanha Plateau marks the passage of dissection surfaces to an area with planing surfaces in interfluvial areas, in addition to undifferentiated pediplane surfaces. The predominant processes are represented by landforms of slightly undulations hills (inclination $2-5 \%$ ) that occur in more than $51 \%$ of the Biome area. It follows the forms of undulating hills (inclination $5-15 \%$ ) with more than $29 \%$ and the flat areas with $16 \%$.

In the Landforms of slightly undulations hills and flat areas (Figure 10A), the most significant elements are the flat and the footslope, occur in the Western portion of the Campanha Plateau (sector 01). The undulating hills mark areas of homogeneous dissection, where the elements shoulder and slopes are representative.

The scaling of topographical levels through slope breaks, as well as the occurrence of hills and buttes, marks a contact area between the Plateau area and the Central Depression (sector 02). In this area there is an elevation defined by the alignment of buttes called Serra do Caverá (Figure 10B) where slope and shoulders elements predominate, in addition to the presence of ridge and valleys. 

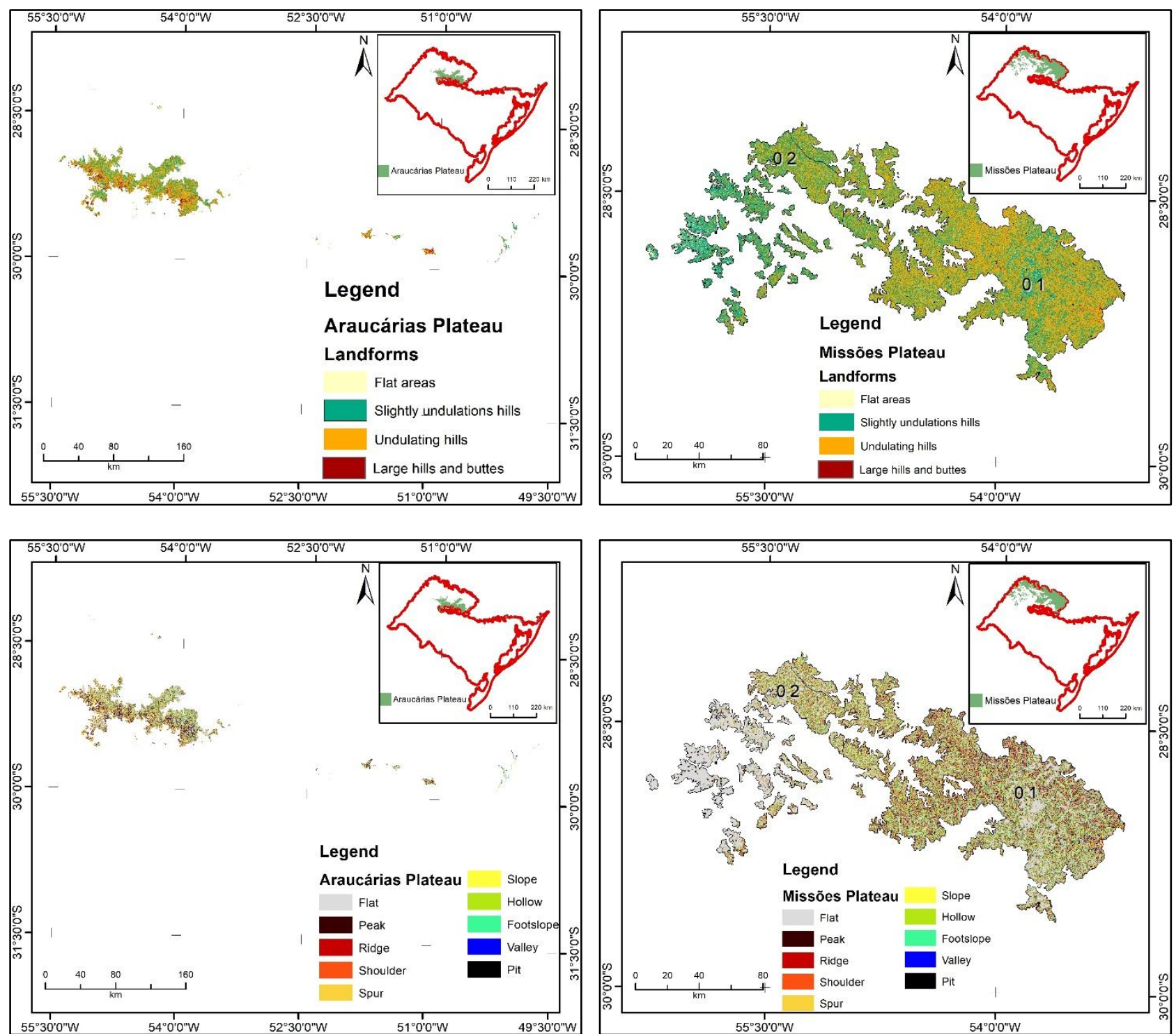

Figure 9: Spatial distribution of the landforms and elements in the Araucárias Plateau and Missões Plateau. Source: authors.
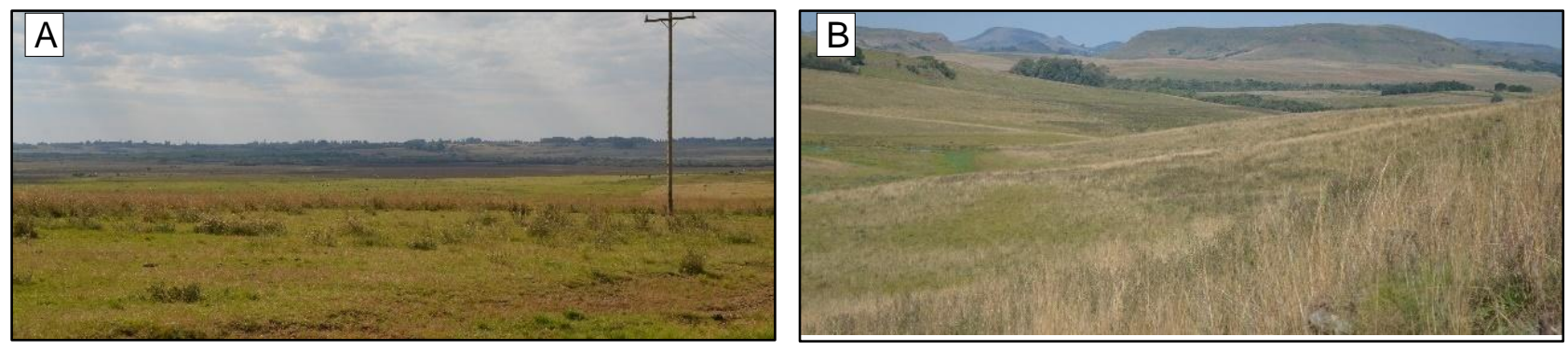

Figure 10: Photographs showing the landforms situations on Campanha Plateau with (A) Sector 01 and Sector 02 (B). Source: authors.

Figure 11 shows the percentages of the landforms and landform elements in the Campanha Plateau and Figure 12 shows the respective spatial distributions. 

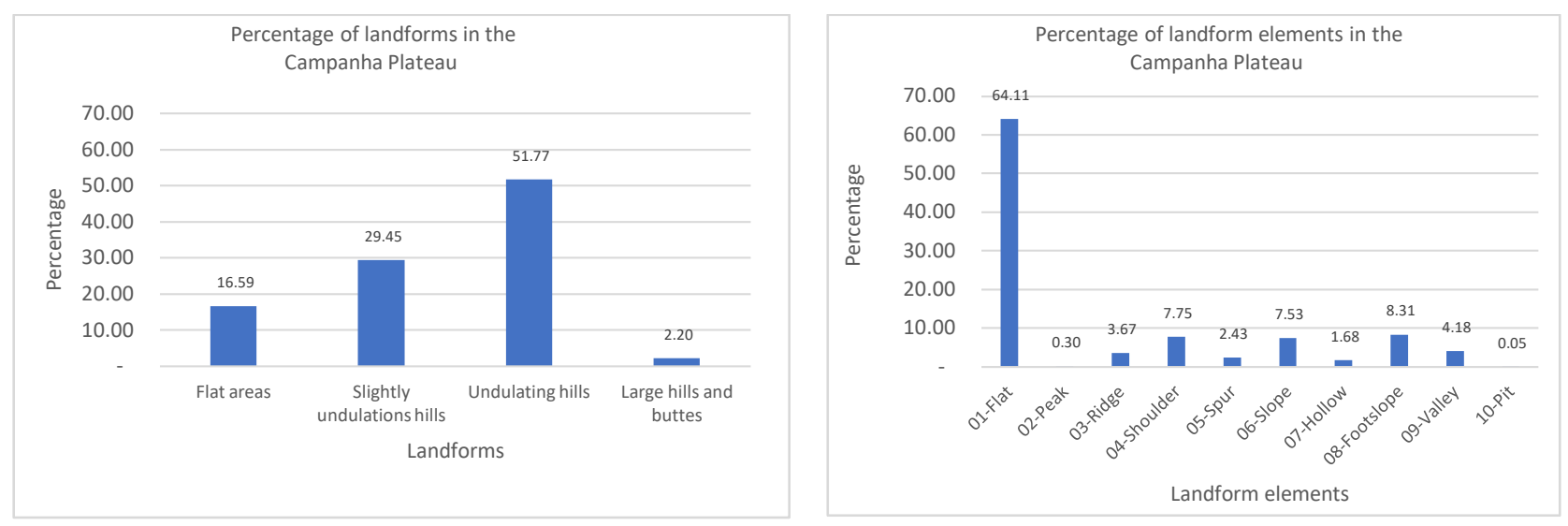

Figure 11: Percentage of landforms and elements in the Campanha Plateau.
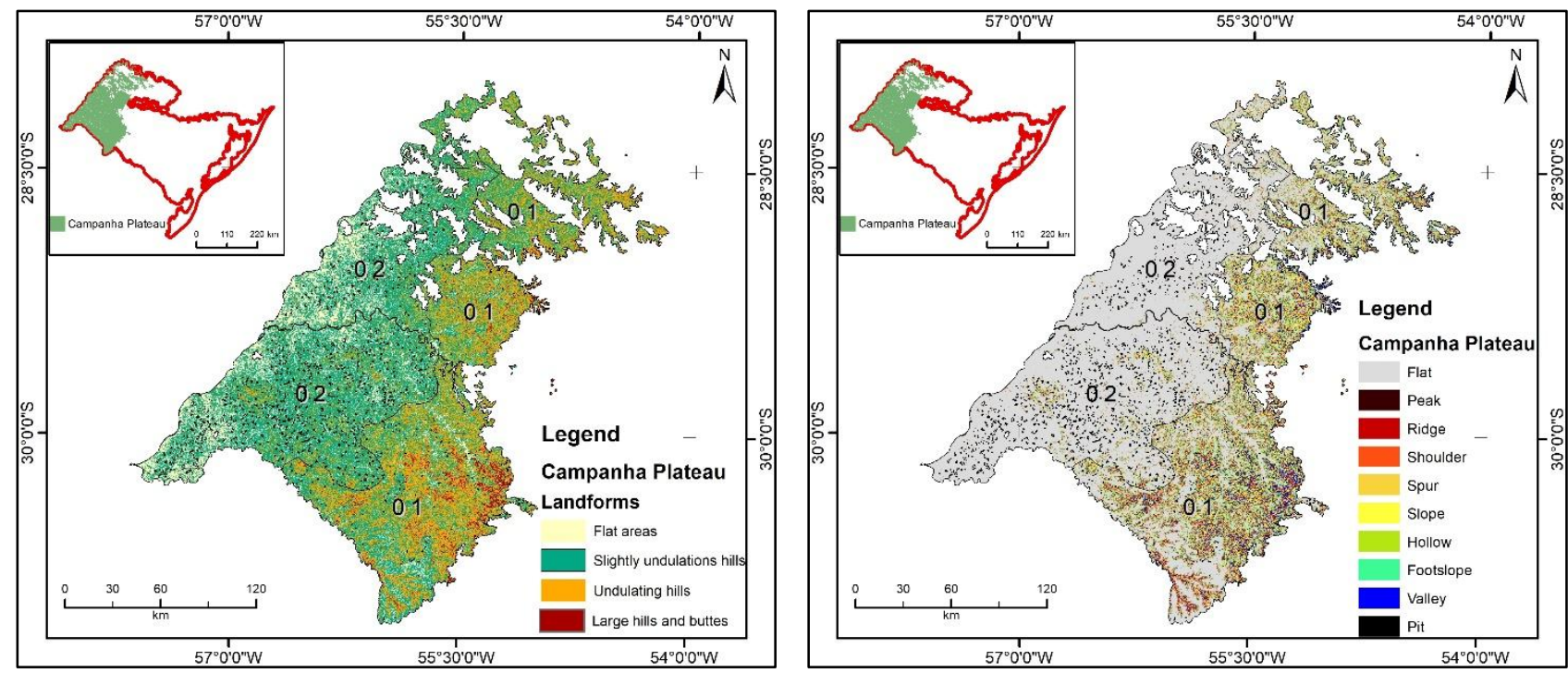

Figure 12: Spatial distribution of landforms and elements in the Campanha Plateau. Source: authors.

The Central Depression, with $23.67 \%$ of the total of the Biome, is divided into two parts: Depression Rio Jacuí and Depression Rio lbicuí-Rio Negro. They represent areas interplanaltic associated with sedimentary rocks in the Paraná Basin. The Central Depression of the Rio Jacuí, located in the east-west segment, occupies $9.5 \%$ of the Biome area and the Depression of the Rio lbicuí-Negro, located in the north-south segment occupies around 14\% of the Biome area. The regions of the Depression Rio Jacuí and Depression Rio lbicuí-Negro show important sequences of accumulation, identified as sector 01, associated with the alluvial portion of the Rio Jacuí, Ibicuí and Santa Maria rivers that are represented by the Landforms of flat areas (inclination $<2 \%$ ) (Figure 13A).

Around the flat areas, homogeneous dissection models and planing models are represented by landforms of slightly undulations hills (inclination $2-5 \%$ ). These landforms are characterized by the flat element with 55\% in the Ibicuí-Negro region and 51\% in the Rio Jacuí unit and by the footslope element with 11\% in both units. The landforms of undulating hills and residual reliefs, with pediments at the base of steep slopes, which represent testimonial buttes (inclination $>15 \%$ and amplitude $<100$ meters) are important in the areas at the base of the Plateau, defining dissection surfaces, marking sector 02 in both regions (Figure13B). These landforms are marked by the significant occurrence of slope and ridges elements, secondary for spur and valleys. The sector 03 in the Rio Jacuí region is characterized by the area of contact with the crystalline basement with landforms undulating hills (inclination $5-15 \%$ ) predominates, represented by elements of the slope, valley and ridge (Figure13C).

In the region of the Depression of the Rio lbicuí-Rio Negro, the sector 03 was defined, for landforms of slightly undulations hills (inclination $2-5 \%$ ) associated with a lineament of buttes (inclination $>15 \%$ and amplitude <100 meters) that mark the contact between the Depression and the Campanha Plateau (Figure 13D). The sector 04 represents an area in Cacequi River basin where dissection processes are marked by landforms of undulating hills and elements of valleys and hollows that define erosive features (Figure 13E). 
At the edge of the basement rocks, sector 05 , there are sandstone rocks of medium to low cohesion, which landforms of undulating hills marked by elements of slope, footslope and shouder (Figure 13F).
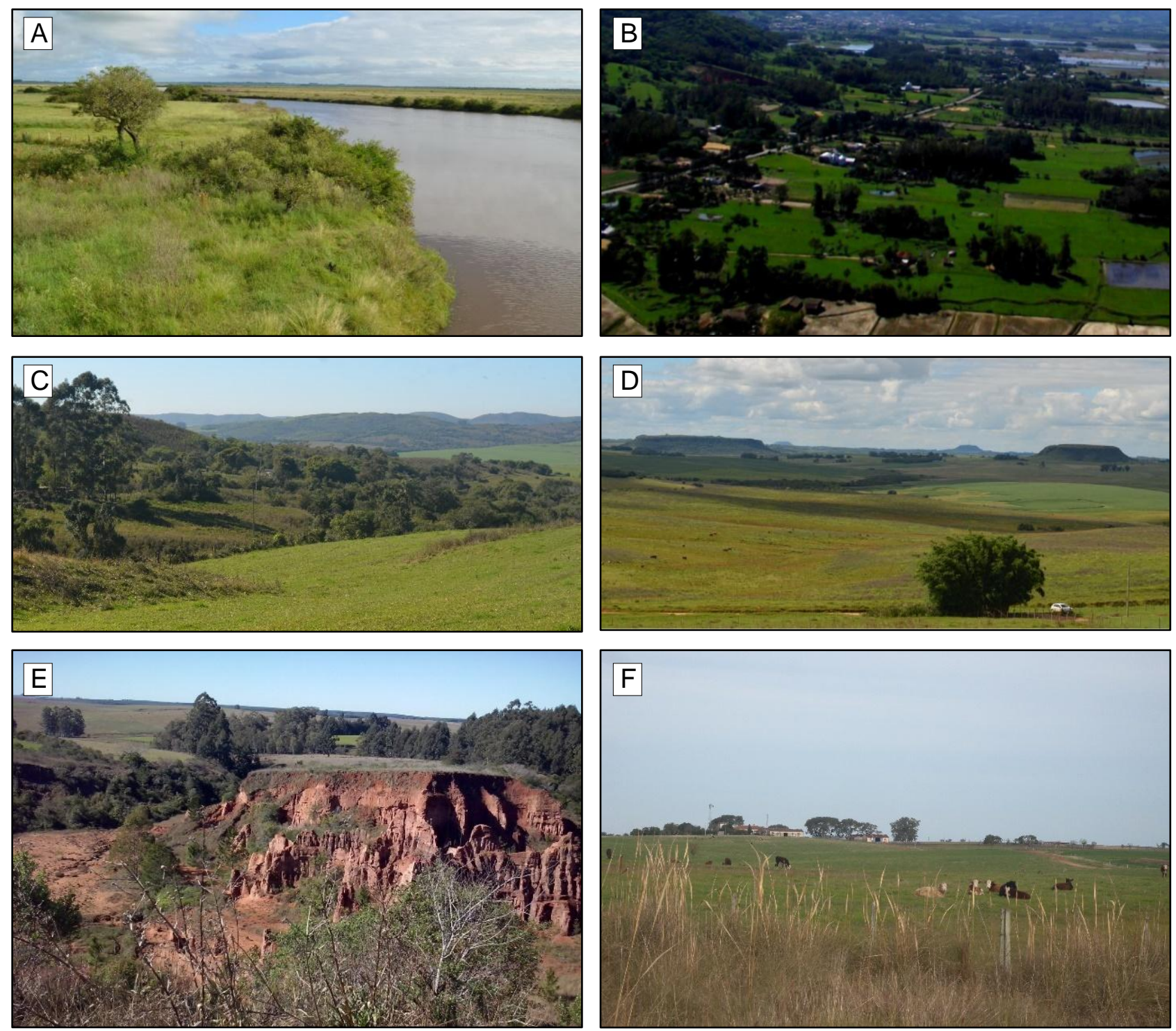

Figure 13: Photographs showing the landforms situations on Central Depression. Sector 01 (A), Sector 02 in the Rio Jacuí (B), Sector 03 in the Rio Jacuí (C), Sector 03 in the Rio lbicuí-Rio Negro (D), Sector 04 in the Rio lbicuí-Rio Negro (E), Sector 05 in the Rio lbicuí-Rio Negro (F). Source: authors.

Figure 14 shows the percentages of the landforms and landform elements in the Depressions of the Rio Ibicuí-Rio Negro and Rio Jacuí and Figure 15 shows the respective spatial distributions.
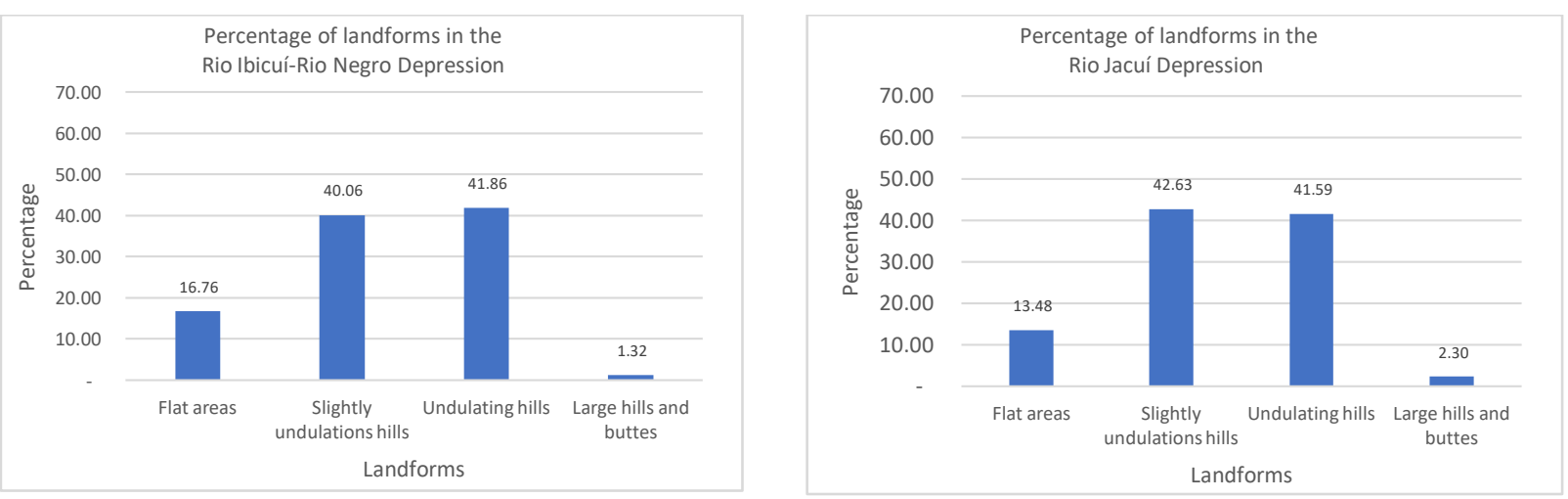

Figure 14: Percentage of landforms and landform elements in the Rio Ibicuí-Rio Negro and Rio Jacuí Depressions. Source: authors. 

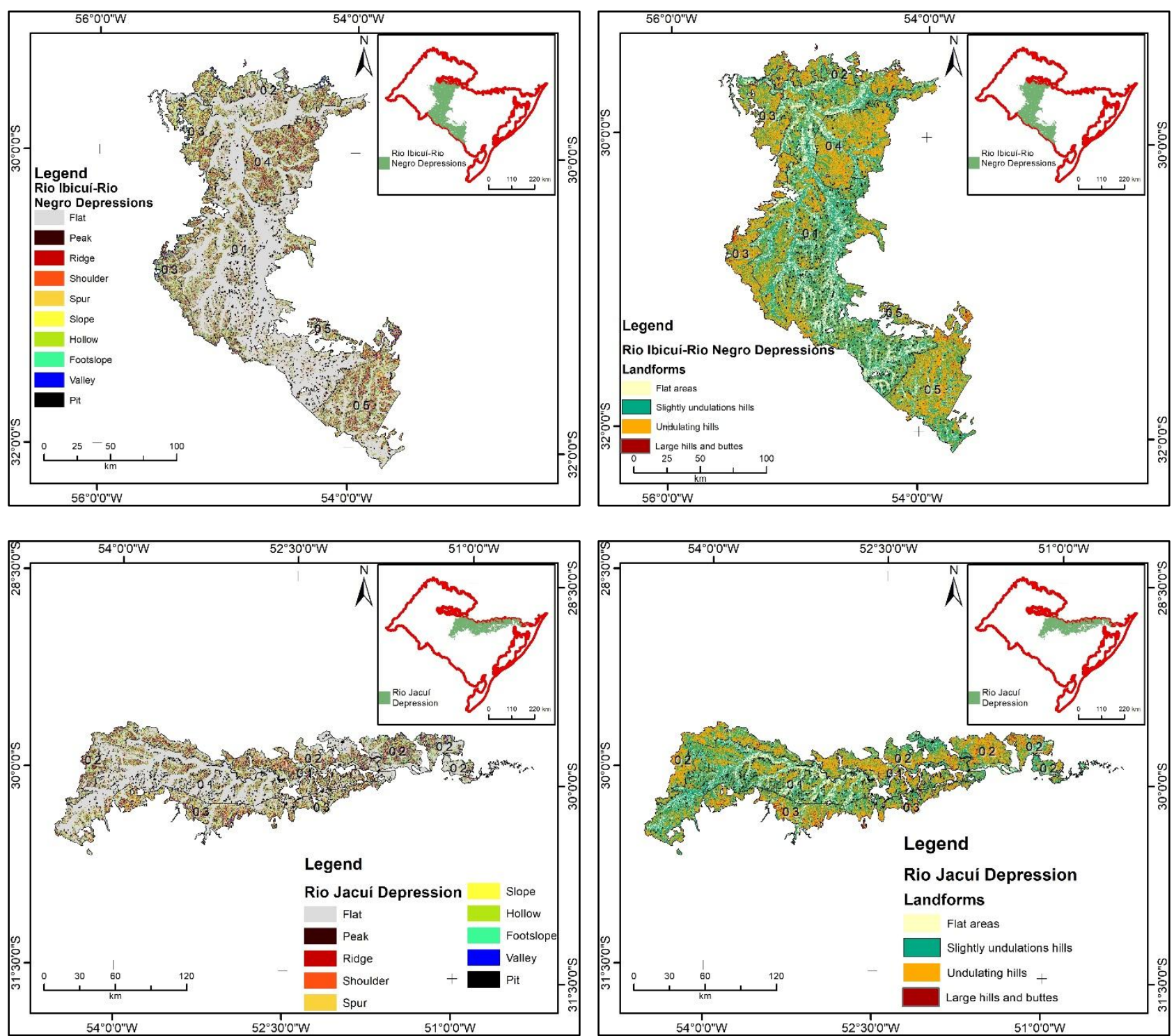

Figure 15: Spatial distribution of landforms and landforms elements in the Depressions of the Rio IbicuíRio Negro and Rio Jacuí. Source: authors.

\subsection{Morphostructural Domain of Basements in Complex Styles}

In this domain, plateau landforms occur, intersected by several structural landforms. In the Pampa Biome, it is represented by the Geomorphological Region of the Sul-Riograndense Rebaixado Plateau, with an area of just over $26 \%$, sculpted in rocks of the volcanic-sedimentary sequence of the Camaquã Basin (PAIM et al. 2000), metamorphic rocks and granite suites.

The landforms of this region was constituted by dissected forms and areas of pediplane surfaces. These models are reflected in landforms of undulating hills and an important occurrence of buttes and large hills forms.

It can be divided into five main sectors:

- (01) The southwestern sector is configured in a more fragmented block formed by acidic volcanic and subvolcanic rocks of the Acampamento Velho Formation, granite-gneissic and granulite rocks (GASTAL, 1999) that resulted in a planing denuded surface, represented by forms of slightly undulations hills (inclination $2-5 \%$ ) and flat areas (inclination <2\%) (Figure 16A). In these areas the characteristic elements are the flat and footslope.

- (02) In the northwest, there is a strip of the pediplane surface associated mainly with metamorphic rocks of the Cambaí Complex, granitoids and sedimentary rocks of the Camaquã Basin. The landforms is 
characterized by undulating hills (inclination $5-15 \%$ ) with elements of the wide slope are very representative and occurrence of shoulder and spur elements (Figure 16B).

- (03) In the central portion comprising the area of the Camaquã Basin, which consists of sedimentary rocks associated with volcanic and volcanoclastic rocks. Develop undulating hills (inclination $5-15 \%$ ) associated with buttes (inclination $>15 \%$ and amplitude $<100$ meters) and large hills (inclination $>15 \%$ and amplitude >100 meters) isoladed of cemented conglomeratic sandstones (Figure 16C). It is represented by elements of slopes and the ridge constituted by elongated elevations with spur and shouder.

- (04) In the central-eastern portion of the Plateau, associated with the Tijucas metamorphic belt, there is an area of strong dissection marked by landforms of hills (inclination $5-15 \%$ ), buttes (inclination $>15 \%$ and amplitude $<100$ meters) and large hills (inclination $>15 \%$ and amplitude $>100$ meters). The elements that characterize are narrow valleys, elongated ridges and slopes (Figure 16D).
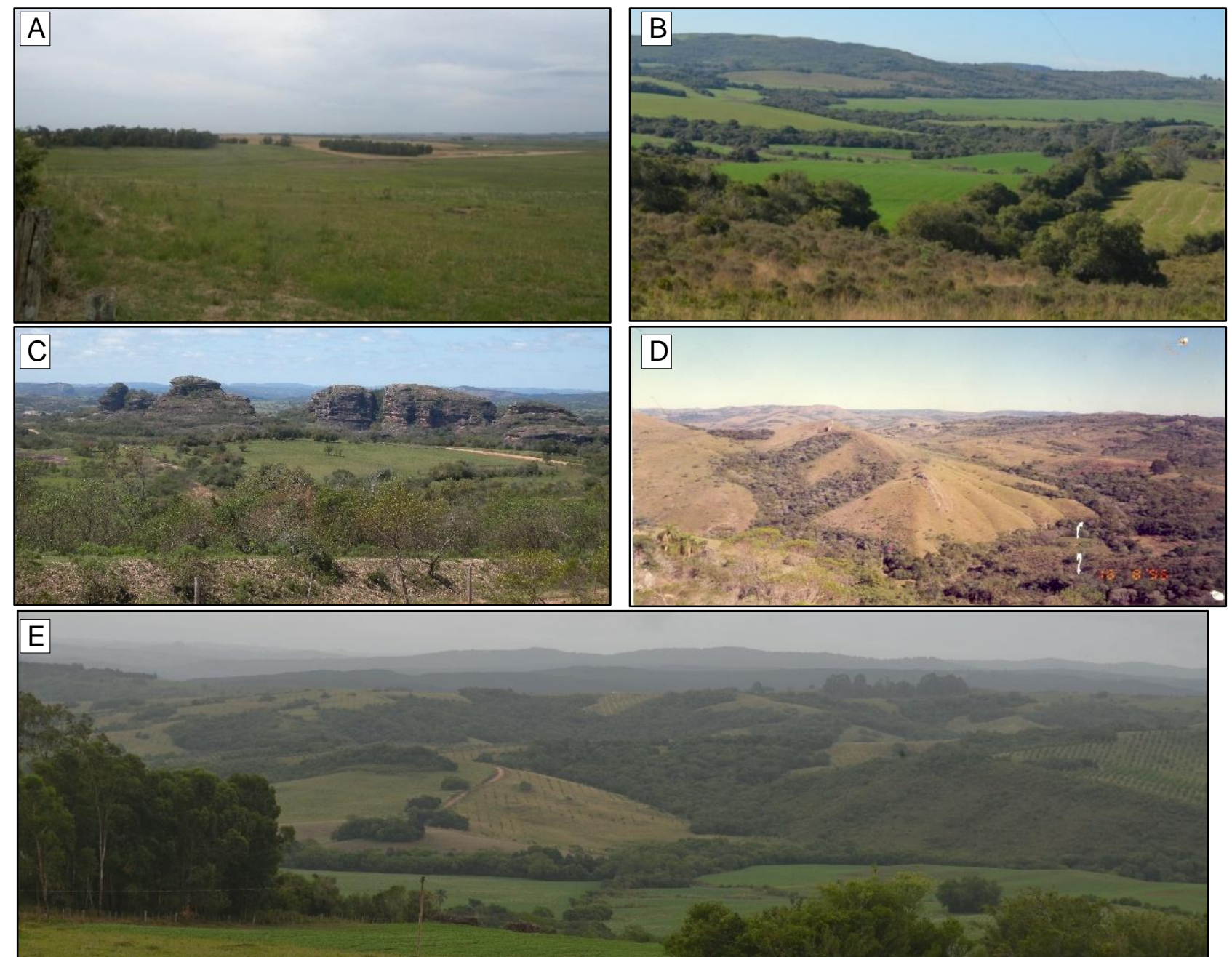

Figure 16: Photographs showing the landforms situations on Sul-Riograndense Rebaixado Plateau. Sector 01 (A), Sector 02 (B), Sector 03 (C), Sector 04 (D), Sector 05 (E). Source: authors.

In the eastern portion associated with the granite-gneiss substrate of the Dom Feliciano Belt (WILDNER et al., 2006) the landforms, predominant, is of undulating hills (Figure 16E). The landform elements that characterize it are wide slopes, valleys and elongated ridges. This sector was subdivided into two parts due to the difference in the landforms characterized by the more significant occurrence of the forms of buttes (inclination $>15 \%$ and amplitude $<100$ meters) and large hills (inclination $>15 \%$ and amplitude $>100$ meters). In the northern portion of sector $05(05 \mathrm{~A})$, it is marked by landforms of greater dissection, evidenced by the forms of buttes and large hills associated with forms of hills. The elements that characterize are slope, ridge and valley. The relief reflects the intrusion of late granitoids, dominantly belonging to the Dom Feliciano suíte. According to Philipp et al (2002) it is the youngest suite of the batholith that presents great compositional, structural and petrographic homogeneity. They represent pink, brown and light gray 
leukogranites, with a predominance of syenogranites, with essential minerals, potassium feld spar and quartz. These minerals are highly resistant, relative to the weathering processes, maintaining the cohesion of the rock and reducing erosion, maintaining the relief.

Figure 17 shows the percentages of the landforms and elements in the Sul-Riograndense Rebaixado Plateau and, Figure 18 shows the respective spatial distributions.
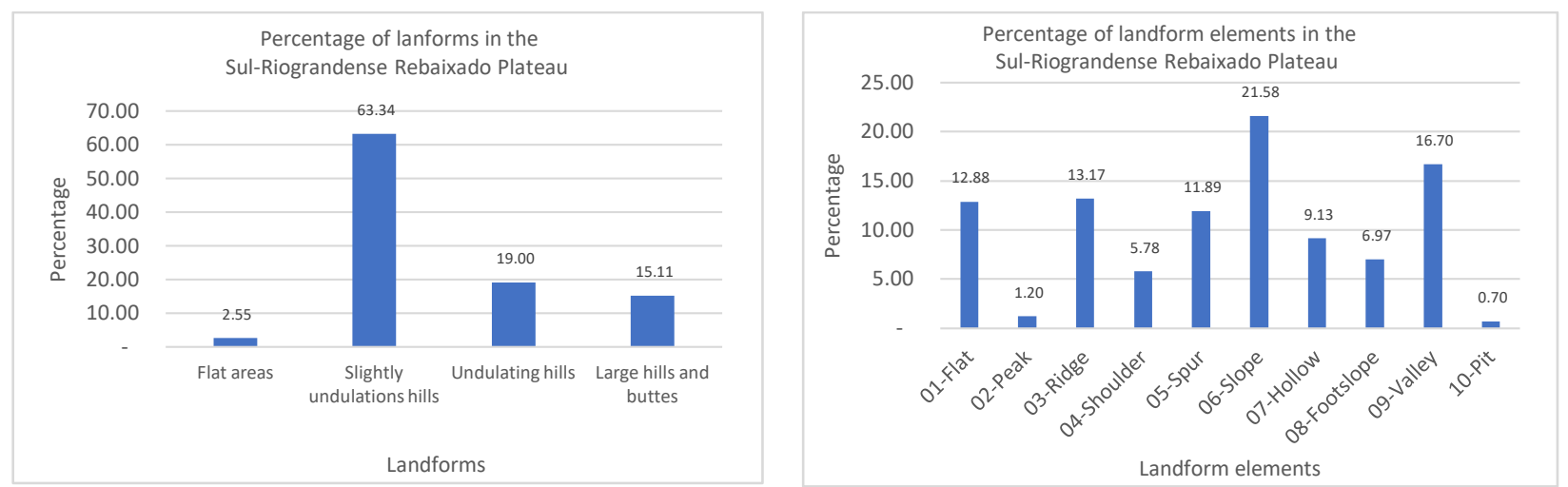

Figure 17: Percentage of landforms and landforms elements in the Sul-Riograndense Plateau. Source: authors.
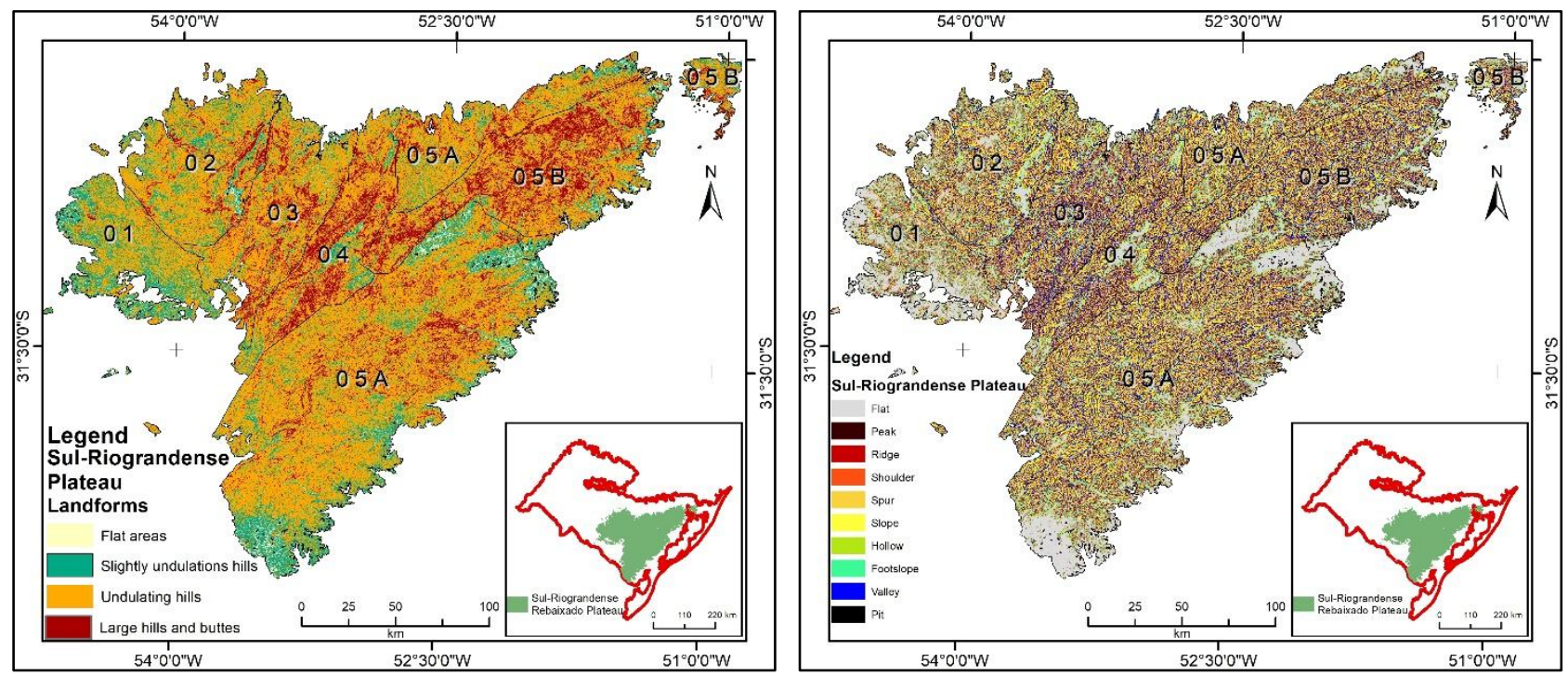

Figure 18: Spatial distribution of the landforms and landforms elements in the Sul-Riograndense Rebaixado Plateau. Source: authors.

\section{Final considerations}

The use of GIS and geoprocessing tools for spatial and geomorphometric analysis, allowed to develop a zoning of the relief present in the Pampa Biome brazilian.

The Pampa Biome presents a great variety of geomorphological aspects, resulting from the differences in the nature of the lithologies and diverse structural characteristics that interacted in the performance of the superficial processes of the past and the present.

In coastal areas is an important broad and extensive flat areas, which dominate the accumulation modeled developing landforms of the flat areas and smooth slopes with the marked presence of the flat element. The occurrence of a dune system in the marine portion, more external, is characterized by the shoulder element.

The area of volcanic rocks there is the Plateau relief represented by the predominance of dissection in the North portion, with landforms of wavy hill, which advances to planing processes towards West and Southwest, represented by landforms of slightly undulations hills and flat areas. 
Associated with sedimentary rocks, there is landforms of depression with important accumulation processes associated with the alluvial bands of the Rio Jacuí, Rio Ibicuí and Rio Santa Maria and of homogeneous dissection and planing, which are represented by forms of slightly undulations hills. The most representative elements are of the flat and footslope.

The relief on the rocks of the Basements is characterized by strong lithostructural control forming an area of Plateau where the forms of undulating hills, buttes and large hills are the dominant.

The zoning of the landforms in the different geomorphological compartments is based in the factors acting in its modeling. In this way, they constitute fundamental data to understand the surface processes and the effects generated by human activities.

The application of a digital relief model to landform analysis and automated classification

of landform elements. The classification derives from attributes such as slope, altitude and descriptive statistics.

The results obtained showed that it is a very efficient technique in the delimitation of distinct and peculiar characteristics that correspond to the geomorphologically recognized units. Therefore, the use in future works of the theme of digital relief analysis can support the construction of geomorphological maps.

\section{Acknowledgments}

The Fundação de Amparo a Pesquisa do Rio Grande do Sul (FAPERGS) and Conselho Nacional de Desenvolvimento Científico e Tecnológico (CNPq).

\section{References}

GASTAL, M. C. P. . The alkaline and shoshonitic intrusives in the region of the Taquarembó Plateau, southern Brazil: Are they genetically related?. Revista Brasileira de Geociências , v. 29, n.1, p. 85-98, 1999.

INSTITUTO BRASILEIRO DE GEOGRAFIA E ESTATÍSTICA (IBGE). Projeto RADAMBRASIL. Levantamento de recursos naturais (Folha SH.22 Porto Alegre e parte das Folhas SH.21 Uruguaiana e SI.22 Lagoa Mirim). 1. ed. Rio de Janeiro: [s.n.], 1986.

INSTITUTO BRASILEIRO DE GEOGRAFIA E ESTATÍSTICA (IBGE). Mapa de Biomas do Brasil, primeira aproximação. 2004. Rio de Janeiro: IBGE. Disponível em: 〈http://www.ibge.gov.br >. Acesso em: 03 jun. 2019.

INSTITUTO DE PESQUISAS TECNOLÓGICAS (IPT). Mapa geomorfológico do Estado de São Paulo. Escala 1:500.000. São Paulo: IPT Publicação 1183. , 1981

IWAHASHI, J.; PIKE, R. J. Automated classifications of topography from DEMs by an unsupervised nested-means algorithm and a three-part geometric signature. Geomorphology, v. 86, n. 3-4, p. 409-440, 2007. ( https://doi.org/10.1016/j.geomorph.2006.09.012)

JASIEWICZ, J.; STEPINSKI, T. F. Geomorphons-a pattern recognition approach to classification and mapping of landforms. Geomorphology, v. 182, 2013. (https://doi.org/10.1016/j.geomorph.2012.11.005)

KRETSCH, J. L. Shuttle radar topography mission overview. 2000, [S.1.]: Institute of Electrical and Electronics Engineers Inc., 2000. p. 276-282. (https://doi.org/10.1109/AIPRW.2000.953635)

LINDMAN, C. A.M. A vegetação no Rio Grande do Sul. Porto Alegre. Livraria Universal, 1906. 356p.

MARCHIORI, J. N. C. Fitogeografia do Rio Grande do Sul - Campos Sulinos. EST Edições, Porto Alegre. 2004. 110p.

MILANI, E. J.; MELO J. H. G.; SOUZA, P. A.; FERNANDES, L.F.; FRANÇA, A. B. Bacia do Paraná.

Boletim de Geociências da Petrobras, Rio de Janeiro, v. 15, n. 2, p. 265-287, maio/nov. 2007. 
MINATEL TINÓS, T. FERREIRA; M, V.; RIEDEL, P. S.; ZAINE, J. E.. Aplicação e avaliação de metodologia de classificação automática de padrões de formas semelhantes do relevo. Revista Brasileira de Geomorfologia, v. 15, p. 353-370, 2014. (http://dx.doi.org/10.20502/rbg.v15i3.455)

MINISTÉRIO DO MEIO AMBIENTE (MMA). Mapa de Cobertura Vegetal. 2004. Brasília: MMA. Disponível em: <https://www.mma.gov.br>. Acesso em 03 abr. de 2020.

MUÑOZ, V. A. Análise Geomorfométrica de Dados SRTM Aplicada ao Estudo das Relações SoloRelevo. 1. ed. São José dos Campos: Dissertação (Mestrado em Sensoriamento Remoto), 2009.

PAIM, P. S. G., CHEMALE, F. \& LOPES, R. C. (2000) A Bacia do Camaquã. In: M. Holz \& L. F. De Ros (eds) Geologia do Rio Grande do Sul, Porto Alegre, p. 231-274.

PHILIPP, R. P.; MACHADO R., NARDI L.V.S.; JEAN MICHEL LAFON J.M. O magmatismo granítico neoproterozóico do Batólito Pelotas no sul do Brasil: novos dados e revisão da geocronologia regional. Revista Brasileira de Geociências 32(2):277-290, junho de 2002.

PINEDA M. J. E.; ROBAINA L. E. S.; TRENTIN, R.; PARTIDA R. D. L. Clasificación de unidades geomorfológicas en la cuenca del Río Neverí, Venezuela. Ra'e Ga: Temático de Geomorfologia. Curitiba, v.41, p. 189 -207, Ago/2017. (http://dx.doi.org/10.5380/raega.v41i0.52344)

ROBAINA, L. E. D. S.; TRENTIN, R.; LAURENT, F. Compartimentação do estado do Rio Grande do Sul, Brasil, através do uso de geomorphons obtidos em classificação topográfica automatizada. Revista Brasileira de Geomorfologia, v. 17, n. 2, 30 jun. 2016. (http://dx.doi.org/10.20502/rbg.v17i2.857)

ROSS, J. L. S. Geomorfologia. Ambiente e Planejamento. 1. ed. São Paulo: Contexto, 1990.

SANTOS V.S.; ROBAINA L.E.S.; TRENTIN R. Definição das Unidades de Relevo na Bacia Hidrográfica do Rio Jaguari - Oeste do RS. Geografia, Ensino \& Pesquisa, Vol. 21 (2017), n.2, p. 197-204.

(https://doi.org/10.5902/2236499423070)

SCHMIDT, J.; HEWITT, A. Fuzzy Land Element Classification from DTMs Based on Geometry and Terrain Position. Geoderma, 2004, vol. 121. Pag. 243-256. (https://doi.org/10.1016/j.geoderma.2003.10.008)

SILVEIRA, R. M. P.; SILVEIRA, C. T. Análise digital do relevo aplicada à cartografia geomorfológica da porção central da Serra do Mar paranaense. Revista Brasileira de Geomorfologia, v. 17, n. 4, 15 dez. 2016. (http://dx.doi.org/10.20502/rbg.v17i4.1063)

SILVEIRA, R. M. P.; SILVEIRA, C. T. Classificação hierárquica automatizada de formas do relevo no estado do Paraná apoiada na modelagem digital do terreno. Revista Brasileira de Geografia Física, v. 8, n. 3, p. 1509-1523, 2015. (https://doi.org/10.26848/rbgf.v8.5.p1509-1523)

TRENTIN R.; ROBAINA L.E.S. Classification of the landform units supported by geomorphometric attributes. Mercator, Fortaleza, v. 15, n.3, p. 53-66, jul./set., 2016. (https://doi.org/10.4215/RM2016.1503.0004)

TRENTIN, R.; ROBAINA, L. E. D. S.; BARATTO, D. D. S. Análise de Elementos do Relevo Através do Topographic Position Index (TPI) da Bacia Hidrográfica do Arroio Puitã - Oeste do Rio Grande do Sul/Brasil. Geography Department University of Sao Paulo, 2016. (https://doi.org/10.11606/rdg.v31i0.100267)

U.S. GEOLOGICAL SURVEY. USGS Global Visualization Viewer. Water-use. [S.l: s.n.]. Disponível em: <earthexplorer.usgs.gov>. 2016

VIDAL-TORRADO, P.; LEPSCH, I. F.; CASTRO, S. S. Conceitos e aplicações das relações pedologiageomorfologia em regiões tropicais úmidas. Tópicos em Ciência do Solo. Viçosa: Sociedade Brasileira de Ciência do Solo, 2005. p. 145-192. 
VILlWOCK, J. A., TOMAZELli, L. J. Planície Costeira do Rio Grande do Sul: gênese e paisagem atual. Regiões da Lagoa do Casamento e dos Butiazais de Tapes, Planície Costeira do Rio Grande do Sul, Brasília: MMA, 2007. 20p.

WILDNER, W. et al. Mapa Geológico do Estado do Rio Grande do Sul - Escala 1:750000. Porto Alegre : CPRM, Serviço Geológico do Brasil. 2006.

(1) (5) (2)

BY 